\title{
Capital Structure Determinants and Their Impact on Firm Value: Evidence From Indonesia
}

\author{
Sutrisno \\ Universitas Islam Indonesia, Yogyakarta, Indonesia
}

\begin{abstract}
This study has two main purposes, i.e., the first is to discover and analyze capital structure determinants, and the second is to discover and analyze the influence of capital structure determinants on firm value in which capital structure treated as a moderating variable. Factors suspected to be determinants of capital structure consist of company growth, profitability, asset structure, leverage, and company size. The population in this study were manufacturing companies listed in Indonesian Stock Exchange. Using purposive sampling method, 125 companies with four years' (2008-2011) observation period were collected. The analysis tool used was multiple regression. The results showed that factors which significantly determined capital structure were fixed asset structure, leverage, profitability, and size, while company growth did not influence capital structure. Meanwhile, with capital structure as a moderating variable, asset structure, leverage, and profitability significantly influence the firm value, while company growth and company size did not influence the firm value.
\end{abstract}

Keywords: capital structure, asset structure, leverage, firm value, firm size

\section{Introduction}

There are three important decisions faced by financial managers, i.e., investment decision, dividend decision, and funding decision (Weston \& Copeland, 1986, p. 3). Funding decision is a decision to select funding sources, either the type or the amount, to form capital structure. Financial managers are demanded to look for funding sources at a cheap cost and with optimum composition, i.e., capital structure which will create the lowest cost of capital. Cost of capital emerged from funding decisions is a consequence which directly emerged from decisions made by managers. Once managers use funds from debts, cost of capital will emerge in the form of interest imposed by creditors, while if funds from the owners (internal funds) used, cost of capital in form of opportunity cost will emerge from the capital. Therefore, if funding decisions are not made carefully, they may create high cost of capital, which will eventually decrease companies' profitability. Brigham and Gapensi (1996, p. 355) stated that one of the most confounding issues in financial management is capital structure of balancing debts with equity.

Capital structure theories change revolutionarily following an article by Modigliani and Miller (1958) which dismisses the theories from traditional approach. According to traditional approach, the value of a firm will change by changing the capital structure. Thus, changing the capital structure will produce optimum value

Sutrisno, Dr., lecturer on doctoral program, Economics Faculty, Universitas Islam Indonesia, Yogyakarta, Indonesia.

Correspondence concerning this article should be addressed to Sutrisno, Economics Faculty Campus, Condongcatur, Depok, Sleman, Yogyakarta, Indonesia. 
for the firm. Modigliani and Miller (1958) stated that there is no relation between the value of a firm and cost of capital through capital structure. The statement is supported by arbitrage argument. Arbitrage will make company's market values be the same even when the company chooses to use debt or owner's capital.

According to Modigliani and Miller (1958), if there is any tax, the change of capital structure becomes relevant. This is because interests paid serve as tax deductible. Companies which use debts pay less than companies which don't. Therefore, companies' using of debts can save tax, which eventually increase the values of the companies and the welfare of the owners.

According to Modigliani and Miller (1958), the bigger are the debts, the higher are the values of the companies. However, in reality, the higher are the debts, the bigger are the risks faced by the companies. Thus, the probability of bankruptcy is bigger. High debts mean that companies must provide money to pay for large amounts of interests, so the probability of default is also high. In case of default, creditors can bankrupt companies, so cost of bankruptcy should be also considered. Therefore, increasing debts will be stagnant at some point and will decrease the values of the companies. Modigliani and Miller's theory combining the cost of bankruptcy and the cost of agency indicates a trade-off between tax saving and cost of bankruptcy.

There are many factors that determine managers' decisions in determining capital structure of their companies. Brigham and Gapensi (1996, p. 39) revealed that there were several factors which influenced capital structure, including sales stability, asset structure, operational leverage, company growth rate, profitability, tax, management's attitude, lender's attitude, market condition, and company's financial condition. Utami (2009) used company size, business risk, growth, asset structure, and profitability as determinants of capital structure. Meanwhile, Afza and Hussaian (2011) added leverage, tangibility, liquidity, and tax as determinants of capital structure in their study on cross-sector industry in Pakistan.

Sabir and Malik (2012) that study oil and gas sector used profitability, liquidity, company size, and tangibility as determinants of capital structure, while A. Chowdhury and S. P. Chowdhury (2010) used earning per share, dividend payout ratio, public owned, fixed asset turnover, long term debt to total asset, current ratio, and sales growth as determinants of capital structure.

From the description above, this study aimed to test the determinants of capital structure and the influence of the determinants on the firm value. Factors suspected to influence capital structure and firm value are company growth, profitability, asset structure, operational leverage, and company size.

\section{Hypothesis Development}

As described above by Modigliani and Miller (1958), if companies use debts, their value of the firm can be increased by adding debts. However, if debts keep increasing overtime, the companies' risks will be high, and the possibility of bankruptcy will emerge. Therefore, there will be trade-off with cost of bankruptcy, if debts keep increasing. Even Myers (1984) with his pecking order theory revealed that in fulfilling fund sources, companies start from the cheapest source, which is retained earnings, then external funding sources (retained earnings and shrinkage), then internal funding source from stock emission.

Mas'ud (2008) found that capital structure proxied by cost of financial disruption had the most significant influence to firm value. The findings of Kesuma (2010) also supported that capital structure influence firm value proxied with stock prices. Optimum capital structure would improve the performance of the companies, as found by Ogbulu and Emeni (2012) in their study in Nigeria. From the description above, the following hypothesis was made: 
$\mathrm{H}_{1}$ : Capital structure significantly affects to firm value

Company growth measures the extent to which companies maintain their economic positions, whether in their industries or overall economic activities (Weston \& Copeland, 1986). Company growth shows companies' survivability in competitive condition. Company growth can be measured by two indicators: (1) sales growth and (2) asset growth. If the sales growth is higher than the cost increase, the company's profit will increase. Total profit received regularly and trend of profit increase are factors which significantly determine companies' survival. Meanwhile, companies with negative sales growth have huge potentials to have lower profit. Thus, if managements do not immediately make improvement efforts, the companies probably can not maintain their survival.

Gill, Biger, Pai, and Bhutani (2009); Akhtar, H. Muhammad, and A. M. Muhammad (2011); and Ilyas (2010) found significant influence of company growth on capital structure. Similarly, Utami (2009), Margaretha and Ramadhan (2010), Priyono (2010), and A. Chowdhury and S. P. Chowdhury (2010) also found significant relation between growth and capital structure.

Meanwhile, asset growth shows asset development from the previous period. Brigham and Gapensi (1996) revealed that companies with fast growth rate relied on a lot of external funding sources. Thus, company growth will improve capital structure. Mas'ud (2008) also found positive relation between growth and capital structure. Signaling theory generally predicts that companies with good growth will use debts to fund their investments. Therefore, the following hypotheses were made:

$\mathrm{H}_{2 \mathrm{a}}$ : Assets growth significantly affects to capital structure

$\mathrm{H}_{2 \mathrm{~b}}$ : Asset growth affects to firm value through capital structure

Profitability is also a variable which influences capital structure. In this study, profitability is represented by return on assets (ROA) obtained by dividing net profit with total company asset. According to Weston and Copeland (1986, p. 713), companies with high return on assets generally use relatively small debts. This is because high return on assets enables companies to increase capitals with retained earnings only. But it is not always the case. Another assumption states that high return on assets means net profit is high, so if companies use large amounts of debts, it will not influence their capital structure, because their ability to pay interests will be still high. High return enables companies to pay most funding needs with internal funds. Myers (1984) with his pecking order theory revealed that there was negative influence of profitability on capital structure. Although, the others found the opposite, such as Gill et al. (2009) that found a positive correlation between profitability and capital structure.

High profitability is expected by investors and stockholders because it can increase stock price as a measure of firm value. Mas'ud (2008) found a positive influence of profitability on firm value. Therefore, the third hypotheses were formulated as follows:

$\mathrm{H}_{3 \mathrm{a}}$ : Profitability significantly affects to capital structure

$\mathrm{H}_{3 \mathrm{~b}}$ : Profitability affects to firm value through capital structure

Operating leverage emerges when companies use assets with fixed operational costs. Operational leverage reflects the influence of the amount of fixed costs on companies’ profit (Weston \& Copeland, 1986, p. 557). In this case, the small change of fixed cost will cause the big profit change. The use of low fixed cost will produce large profit. This large profit enables companies to fund most of their funding needs with internally produced funds. The higher is the profit, the lower is the need for external fund (debts). Thus, the capital structure will be lower. Afza and Hossain (2011) and A. Chowdhury and S. P. Chowdhury (2010) used leverage variable as a 
factor influencing capital structure. Similarly, Kesuma (2010) and Jono and Lina (2010) also use leverage as a factor influencing capital structure. Thus, we made the fourth hypotheses as follows:

$\mathrm{H}_{4 \mathrm{a}}$ : Operating leverage significantly affects to capital structure

$\mathrm{H}_{4 \mathrm{~b}}$ : Operating leverage affects to firm value through capital structure

Asset structure is classified into two main parts. The first is current asset (including cash, short-term investment, notes receivable, stock, income receivables, and advance money). The second is non-current asset (including long-term investment, fixed asset, and intangible fixed asset). Most industrial companies invest their capitals in fixed asset, usually by using the owner's capital as the first priority while foreign capital is used as a complement. It can be related to conservative financial structure in which the owner's capital used to cover at least fixed assets and the other assets. Sabir and Malik (2012) and Ilyas (2010) used asset structure as one determinant influencing capital structure. So do Hossain and Ali (2012) that conducted their study in Malaysia. Therefore, we also formulated the fifth hypotheses as follows:

$\mathrm{H}_{5 \mathrm{a}}$ : Assets structure significantly affects to capital structure

$\mathrm{H}_{5 \mathrm{~b}}$ : Assets structure affects to firm value through capital structure

One of the benchmarks that can be used to show companies' size is the amount of their asset. Big assets show that companies have reached a maturity stage where their cash flows are positive and are considered to have good prospect in a relatively long period of time. Big assets also signify that the companies are more stable and more able to produce profits than those with small assets (Gill et al., 2009).

Asset reflects the scale of a company. Large companies usually have large assets as well, and vice versa. Theoretically, bigger companies have bigger certainty than small companies. Thus, it will reduce the level of uncertainty of the companies' future prospects. This can help investors in predicting risks which may happen if they invest in those companies. Mas'ud (2008) and Ilyas (2010) used company size as a factor influencing capital structure, and so do Afza and Hossain (2011) and Gill et al. (2009). Thus, the author made the sixth hypotheses as follows:

$\mathrm{H}_{6 \mathrm{a}}$ : Firm size significantly affects to capital structure

$\mathrm{H}_{6 \mathrm{~b}}$ : Firm size affects to firm value through capital structure

\section{Research Method}

\section{Population and Sample}

The population of this study were all manufacturing companies listed in Indonesian Stock Exchange from 2008 to 2011. The samples taken to represent the population were all sectors in the stock exchange. Samples were 125 companies collected by purposive sampling by considering the representativeness of each industrial sector.

\section{Variables and Measurements}

The variables of this study consisted of two variables, i.e. dependent variables and independent variables. The following are the variables used in this study and the measurement details (Table 1).

\section{Analysis Model}

Multiple regression was used to analyze the data. Equation 1 was the model to analyze the capital structure determinants and Equation 2 was the model to analyze the influence of the determinants on firm's value through capital structure as a moderating variable. 


$$
\begin{gathered}
C S=\alpha+\beta_{1} F G r+\beta_{2} R O E+\beta_{3} L e v+\beta_{4} F A R+\beta_{5} S I Z E+\varepsilon_{i} \\
M B V R=\alpha+\beta_{1} F G r^{*} C S+\beta_{2} R O E^{*} C S+\beta_{3} L e v{ }^{*} C S+\beta_{4} F A R^{*} C S+\beta_{5} S I Z E^{*} C S+\varepsilon_{i}
\end{gathered}
$$

Table 1

\begin{tabular}{|c|c|c|c|}
\hline No & Variables & Proxies & Measurements \\
\hline 1 & Firm value & MBVR & Stock market price/book value per share \\
\hline 2 & Capital structure & CS (DER) & Debt to equity ratio \\
\hline 3 & Assets growth & FGr & $\left(\mathrm{TA}_{\mathrm{t}}-\mathrm{TA} \mathrm{A}_{\mathrm{t}-1}\right) / \mathrm{TA} \mathrm{t}_{\mathrm{t}}$ \\
\hline 4 & Profitability & ROE & Earning after tax/equity \\
\hline 5 & Leverage operasi & LEV & \% Change in EBIT/\% change in sales \\
\hline 6 & Assets structure & FAR & Fixed assets/total assets \\
\hline 7 & Firm size & SIZE & Logaritma natural total asset \\
\hline
\end{tabular}

Variables and Measurement Variables

\section{Result}

\section{Capital Structure Determinants}

In this study, several variables suspected to influence capital structure were used. The variables were profitability, company growth, asset structure, operational leverage, and company size. After performing statistical analysis, we obtained the results as follows:

Table 2

The Result of Regression Test

Independent Variable: $C S$

\begin{tabular}{lllll}
\hline Variable & Coefficient & Std. error & t-statistic & Prob. \\
\hline C & -0.182478 & 0.087487 & -2.085776 & 0.0382 \\
FGR & -0.007308 & 0.03126 & -0.233786 & 0.8154 \\
FAR & 0.33881 & 0.04681 & 7.237986 & 0 \\
LEV & -0.000132 & $9.54 \mathrm{E}-05$ & -1.387744 & 0.0466 \\
ROE & -0.003845 & 0.00169 & -2.274845 & 0.0239 \\
SIZE & 0.014853 & 0.006816 & 2.179035 & 0.0304 \\
\hline
\end{tabular}

From Table 2 above, it can be concluded that from the five variables included in the model, only company growth has insignificant influence on capital structure. It is shown by probability value of FGR that is much bigger than alpha $1 \%, 5 \%$, and $10 \%$. Meanwhile, asset structure (FAR) has significant influence, as shown by probability value of 0.000 that is smaller than the alpha. Operational leverage also influences capital structure significantly with probability value of $4.66 \%$ that is smaller than the $5 \%$ alpha. Operational leverage has negative influence on capital structure, meaning if operational leverage increases, capital structure will decline. Meanwhile, profitability has statistical probability value of $2.39 \%(<5 \%)$ which means that profitability also significantly influences capital structure. Profitability also has negative influence on capital structure. Meanwhile, company size also has positive and significant influence on capital structure.

\section{Value of the Firm and Capital Structure as Moderating Variable}

Capital structure partially influences firm's value, while there are determinants of capital structure which also influence it statistically. This study attemps to analyse whether want to test whether the determinants of capital structure will also influence firm's value through capital structure as the moderating variable. Table 3 provides the results. 
Using capital structure as a moderating variable, this research found that, from the five determinants included in the model, only three variables significantly influence companies' value through capital structure. They were operating leverage, return on equity, and firm size. Company growth did not influence the value of the company, as seen from its probability value that is bigger than $1 \%, 5 \%$, and $10 \%$ alpha (53.88\%). Similarly, asset structure (FAR) did not also influence companies' value as shown by its probability that is also bigger than the alpha. Meanwhile, operational leverage produces the probability value which is smaller than $5 \%$ alpha (1.4\%). So do the other two variables. It meant that the last three variables, LEV, ROE, and SIZE had a significant impact on firm's value.

Table 3

The Result of Rgeression Test

Dependent Variable: $M B V R$

\begin{tabular}{lllll}
\hline Variable & Coefficient & Std. error & t-statistic & Prob. \\
\hline C & 13.16219 & 3.600364 & 3.655795 & 0.0003 \\
FAR ${ }^{*}$ CS & 11.92912 & 65.29211 & 0.182704 & 0.8552 \\
FGR ${ }^{*}$ CS & 32.21325 & 52.3306 & 0.615572 & 0.5388 \\
LEV ${ }^{*}$ CS & 0.512358 & 0.157816 & 3.246562 & 0.0014 \\
ROE ${ }^{*}$ CS & -11.09091 & 5.660612 & -1.959312 & 0.0414 \\
SIZE*CS & -2.751544 & 3.548593 & -0.77539 & 0.0439 \\
\hline
\end{tabular}

\section{Discussion}

Capital structure significantly influenced the value of the company, but the influence was negative, meaning the bigger is the capital structure, the smaller is firm value. This happened because the bigger is the capital structure, the larger is the interest expense. This contradicted the findings of Modigliani and Miller (1963) which revealed that with tax, bigger debts will increase firm value. However, this findings supported Mas'ud (2008) and Kesuma (2010) who found significant influence of capital structure of firm value. Similarly, Gupta, Prasanth, Aman, Srivastava, Dinesh, and Sharma (2011) that studied stock market in India also found significant and negative influence of capital structure on firm value. Ogbulu and Emeni (2012) and Mesulis (1983) also confirmed significant influence of capital structure on firm value.

Company growth which was suspected to have significant impact on capital structure was found to have insignificant influence. This was understandable because companies with high growth usually require large equity (Myers, 1984). However, Mas'ud (2008) found a positive and significant influence of growth on capital structure. Company growth also insignificantly influenced the value of the company through capital structure. This is consistent with the study of A. Chowdhury and S. P. Chowdhury (2010) who found insignificant influence of company growth on capital structure. Meanwhile, Burhanuddin (2009) found a positive influence of company growth on firm value proxied by stock price.

Asset structure proxied by fixed assets ratio (FAR) significantly influenced capital structure. The increase of fixed asset needs to operate a company required large funds. Thus, if funds were taken from debts, capital structure would increase capital structure. Mas'ud (2008), Jono and Lina (2010) also found positive influence of asset structure on capital structure. This finding was supported by the studies of Utami (2009), Margaretha and Ramadhan (2010), and Hossain and Ali (2012). Meanwhile, the influence of asset structure on firm value moderated by capital structure was not significant, meaning bigger fixed assets did not influence the size of 
firm value. This was consistent with the findings of Kesuma (2010) and Gill et al. (2011) who found insignificant influence of asset structure on firm value. The same result is also discovered by Sabir and malik (2012). However, Akhtar et al. (2011), Mas'ud (2008), and Utami (2009) found significant influence of asset structure on firm value. Similarly, Hossain and Ali (2012) also discovered significant influence.

In operational leverage variable, a significant influence was discovered on capital structure. It supported the result of Barral (2004) who conducted a study in Nepal. Similarly, Kesuma (2010) who studied public companies in Indonesia also found a significant relation between operational leverage and capital structure. However, several researchers found the opposite, such as A. Chowdhury and S. P. Chowdhury (2010) and Priyono (2010). Meanwhile, when moderated by capital structure, the influence of operational leverage on firm value was proven to be statistically significant. Kesuma (2010) discovered the same results while A. Chowdhury and S. P. Chowdhury (2010) discovered the opposite, which is no significant influence.

Profitability proxied by return on equity (ROE) had positive and significant influence on capital structure, which means high level of profit increased capital structure. This research result supported the findings of Hossain and Ali (2012), Barral (2004), Margaretha and Ramadhan (2010), Gill et al. (2009), and Afza and Hossain (2011) who also found a positive and significant influence of profitability on capital structure. Akhtar et al. (2011) also discovered a significant influence of profitability on capital structure, but the influence is negative. It's possible if companies' capital structure policies use pecking order theory in which in the context of high profitability, managements use more profit to fund additional funding needs. However, there were researchers such as Mas'ud (2008), Kesuma (2010), and Mesulis (1983) who found that profitability did not significantly influence capital structure. Related to firm value, this study found that profitability significantly influenced firm value through capital structure. It means that the higher is profitability, the higher is firm value. This findings supported the findings of Mesulis (1983), as well as Mas'ud (2008) and Kesuma (2010) who found significant influence of profitability on firm value.

Company size measured by natural logarithm of total asset is often used as a control variable in several researches. This study found significant influence of company size on capital structure. The size strongly influenced the decisions of using debts in capital structure, especially the ability to obtain debts (Mas'ud, 2008). Margaretha and Ramadhan (2010), Afza and Hossain (2011), and Seftianne and Handayani (2011) also found positive and significant influence of company size on capital structure. However, Akhtar et al. (2011) found significant but negative influence of size on capital structure. Related to the firm's value moderated by capital structure, significant and positive influence of company size on firms' value was found. It showed that the larger is the company, the higher is the potential increase of its stock price. Mas'ud (2008) and Mesulis (1983) also found a positive influence of company size on firm value.

\section{Closing}

The research found that the relevant capital structure determinants in industrial companies in Indonesia are profitability, operational leverage, asset structure, and company size. While the determinant that insignificantly influences capital structure is company growth. Of determinants that significantly influence capital structure, leverage, and profitability is found to have a negative influence on capital structure. It means that if the operational leverage and the profitability increase, capital structure will decline.

From the second analysis testing the influence of capital structure determinants on firm value in which capital structure treated as a moderating variable, we found that capital structure had negative and significant 
influence on firm value. It showed that bigger debts (higher capital structure) will decrease profitability. Variables significantly influencing firm value through capital structure were operational leverage, profitability, and company size. Meanwhile, company growth and asset structure had no significant influences.

\section{References}

Afza, T., \& Hossain, A. (2011). Determinants of capital structure across selected manufacturing sectors of Pakistan. International Journal of Humanities and Social Science, 1(12), 254-262.

Akhtar, P., Muhammad, H., \& Muhammad, A. M. (2011). The determinants of capital structure: A case from Pakistasn textile sector. International Conference on Business and Management.

Barral, K. J. (2004). Determinants of capital structure: A case study of listed companies of Nepal. Journal of Nepalese Business Studies, 1(1), 1-13.

Brigham, U. F., \& Gapensi, L. C. (1996). Intermediate financial management (10th ed.). Tokyo: The Dryden Press.

Burhanuddin. (2009). The influaence of earning per share, firm growth, and interest rate to stock price. Journal of Hipotesis, 1(2), 83-94.

Chowdhury, A., \& Chowdhury, S. P. (2010). Impact of capital structure on firm's value: Evidence from Bangladesh. Peer-Reviewed and Open Access Journal, 3(3), 11-122.

Gill, A., Biger, N., Pai, C., \& Bhutani, S. (2009). The determintant of capital structure in the service industry: Evidence from United States. The Open Business Journal, 2, 48-53.

Gupta, Prasanth, Aman, Srivastava, Dinesh, \& Sharma. (2011). Capital structure and financial performance: Evidence from India. Working paper. Kalteng: Universitas Darwan Ali.

Hossain, M. F., \& Ali, M. A. (2012). Impact of firm specific factors on capital structure decision: An empirical study of Bangladeshi companies. International Journal of Business Research and Management, 3(4), 163-182.

Ilyas, J. (2010). The determinants of capital structure: Analysis of non financial firms listed in Karachi Stock Exchange in Pakistan. Journal of Management Science, 2(2), 301-307.

Jono, \& Lina. (2010). Factord affecting capital structure. Jurnal Bisnis dan Akuntansi, 12(2), 81-96.

Kesuma, A. (2010). Factors affecting capital structure and its influence on the share price of real estate companies in Indonesia Stock Exchange. Working paper. Kalteng: Universitas Darwan Ali.

Margaretha, F., \& Ramadhan, A. R. (2010). Factors affecting the capital structure of manufacturing industry in Indonesia Stock Exchange. Jurnal Akuntansi dan Bisnis, 12(2), 119-130.

Mas'ud, M. (2008). Analisis faktor-faktor yang mempengaruhi struktur modal dan Hubungannya terhadap Nilai Perusahaan. Jurnal Manajemen dan Bisnis, 7(4), 82-99.

Mesulis, \& Ronald, W. (1983). The impact of capital structure change on firm value: Some estimates. Journal of Finance, 38(1), 107-126.

Modigliani, F., \& Miller, M. (1958). The cost of capital, corporate finance, and theory of investment. American Economic Review, 48, 261-297.

Modigliani, F., \& Miller, M. (1963). Corporate income taxes and the cost of capital: A correction. American Economic Review, 53, 433-443.

Myers, S. C. (1984). The capital structure puzzle. Journal of Finance, 39(3), 575-592.

Ogbulu, O. M., \& Emeni, F. K. (2012). Capital structure and firm value: Empirical evidence from Nigeria. International Journal of Business and Social Science, 3, 252-261.

Priyono, A. A. (2010). Faktor-Faktor yang mempengaruhi struktur modal pada perusahaan manufaktur yang terdaftar di bei. Unisma: Working Paper.

Sabir, M., \& Malik, Q. A. (2012). Determinants of capital structure-A study of oil and gas sector of Pakistan. Interdisciplinary Journal of Contemporary Research in Business, 3(10), 395-400.

Seftianne, \& Handayani, R. (2011). Factors affecting capital structure on manufacture public company. Journal Business and Accounting, 13(1), 39-56.

Utami, E. S. (2009). Faktor-faktor yang mempengaruhi struktur modal perusahaan manufaktur. Fenomena, 7(1), 39-47.

Weston, J. F., \& Copeland, T. E. (1986). Managerial finance (9th ed.). Japan: The Dryden Press Company. 